\title{
ESTIMATE OF ELASTIC PROPERTIES INCLUDING PORE GEOMETRY EFFECT ON CARBONATES: A CASE STUDY OF GLORIETA-PADDOCK RESERVOIR AT VACUUM FIELD, NEW MEXICO
}

\author{
Irineu de A. Lima Neto and Roseane M. Misságia \\ Recebido em 21 julho, 2011 / Aceito em 30 janeiro, 2012 \\ Received on July 21, 2011 / Accepted on January 30, 2012
}

\begin{abstract}
In general, carbonate rocks are composed by heterogeneous pore systems. Pore heterogeneity can be expressed by a combination of pore geometries, correlating the changing effect of the elastic parameters to 4-D seismic sensitivity. Based on the Kuster-Toksöz model, this work characterizes and classifies different degrees of porosity according to the following types: 1) round or spherical pores - moldic, vuggy or intraframe porosity; 2) interparticle pores - intercrystalline porosity; and 3) microporosity or microcracks - fractures and channel occurrences. The methodology was applied to the Glorieta-Paddock carbonate reservoir at Vacuum field, New Mexico, to estimate bulk and shear moduli, rock density and seismic velocities under dry conditions and saturated by homogeneous fluid. The results indicated the greater potential of the Upper Paddock Formation to store fluids and the higher seismic sensitivity, due to the geometry of the interparticle porosity and the presence of microfractures in limestone, which results in decreased rock rigidity and increased seismic sensitivity to saturation by fluids. However, Lower Paddock and Glorieta formations, consisting of dolomites with spherical interparticle porosity, showed a reduced seismic sensitivity due to increased rock rigidity. Under the conditions of this study, the methodology proposed by Kuster-Toksöz was more adequate to express the occurrences of seismic velocity anomalies compared to Gassmann's model.
\end{abstract}

Keywords: pore geometry, carbonate reservoir, seismic sensitivity.

RESUMO. Rochas carbonáticas geralmente possuem um sistema de poros heterogêneo. A heterogeneidade de poros pode ser expressa por uma combinação de geometrias porosas, correlacionando o efeito de mudanças nos parâmetros elásticos à sensibilidade sísmica 4D. Este trabalho se baseia no modelo de Kuster-Toksöz para caracterizar e classificar porosidades com possibilidades de variação entre os tipos: 1) poros arredondados ou esféricos - ocorrência de porosidade móldica, vugular ou intrapartículas; 2) porosidade interpartículas - de caráter intercristalino; e 3) poros fraturados ("cracks") ou microporosidades - ocorrência de microfraturas ou microfissuras e canais. Com a aplicação da metodologia no reservatório carbonático Glorieta-Paddock, no campo de Vacuum - Novo México foi possível estimar os módulos de incompressibilidade e de cisalhamento, densidade e velocidades sísmicas da rocha, sob condições drenada e saturada por fases homogêneas de fluidos. Os resultados obtidos indicaram que a formação Paddock Superior tem maior potencial para armazenar fluidos, e maior sensibilidade sísmica, atribuídos ao aspecto de poros interpartículas sob influência de microfraturas no calcário, que se reflete em um menor valor de rigidez da rocha e potencializa a sensibilidade sísmica à saturação por fluidos. Entretanto, as formações Glorieta e Paddock Inferior, constituídas por dolomitos com forma esférica de poros interpartículas, apresentaram uma redução da sensibilidade sísmica em virtude do incremento de rigidez da rocha. Pelas condições impostas neste estudo, é possível vislumbrar que a metodologia proposta por Kuster-Toksöz, quando comparada ao modelo de Gassmann, mostrou-se mais adequada para expressar a ocorrência de anomalias nas velocidades sísmicas.

Palavras-chave: geometria de poros, reservatório carbonático, sensibilidade sísmica. 


\section{INTRODUCTION}

Extensive studies of carbonate reservoir rocks have been observed recently, since they constitute the largest oil and gas reserves worldwide. Therefore, studies correlating the seismic response of carbonate rock physical properties applying the timelapse or 4D seismic techniques are important in reservoir characterization and monitoring (Jack, 1997).

Carbonate reservoirs, in general, have heterogeneous pore systems consisting of vugs, molds, channels and microfractures. Different types of pores and porosity imply in several elastic moduli that impact seismic properties, shear $\left(V_{S}\right)$ and compressional wave $\left(V_{P}\right)$ velocities and density $(\rho)$. Furthermore, the properties of the fluids present in the pores also change seismic behavior. Thus, mineralogy, pore geometry, porosity, as well as saturation fluid properties, temperature and pressure, are important factors that affect seismic velocity (Wang, 1997). Some theoretical models applied to siliciclastic rocks, for example, Biot-Gassmann (Biot, 1956) take into consideration only average porosity of the rock matrix, because it implicitly assumes homogeneous pore distribution in the rock. However, in carbonates, it is necessary to propose models that best represent the pore system due to heterogeneities resulting from diagenesis. Kuster-Toksöz model (Kuster \& Toksöz, 1974) takes into account the effect of pore geometry, porosity and rocky matrix mineralogy, and all inclusions that contribute to the prediction of $V_{P}$ and $V_{S}$. Berryman (1995), Kumar \& Han (2005), Wang et al. (2009), Xu \& Payne (2009), Wang \& Sun (2010) and Payne et al. (2010) used the Kuster-Toksöz model and proposed methodologies aimed at its improvement.

Acuna (2000) developed a 4D multicomponent seismic characterization of the Glorieta-Paddock carbonate reservoir, at Vacuum Field, New Mexico. One of the objectives of the study was to use the available data to quantify the effect of anisotropy and anomalies observed in velocity dispersion of fluid saturated rocks, regarding the lithologies of interest: dolomite in Glorieta formation; limestone in Upper Paddock formation; and, dolomite in Lower Paddock formation. Acuna (2000) concluded that the model developed according to the Gassmann theory (Gassmann, 1951) did not satisfactorily represent the anomalies observed in the Glorieta-Paddock carbonate reservoir due to its limitation to represent the occurrence of microfractures in the Glorieta and Paddock formations.

This study strategically proposes to use the Kuster-Toksöz model to evaluate the Glorieta-Paddock reservoir, in order to consider the effect of pore geometry and fluid inclusion. Therefore, a strategy to classify the pores in clean carbonates was de- veloped. Then, elastic modulus and density of carbonate rocks were estimated, simulating fluid saturation conditions, improving the understanding of $V_{P}$ and $V_{S}$; and inversion of elastic parameters, important to reservoir characterization. Furthermore, the results of both models, Kuster-Toksöz and Gassmann theory were compared.

\section{METHODOLOGY}

Anselmetti \& Eberli (1999), Kumar \& Han (2005) and Xu \& Payne (2009) demonstrated that carbonate rocks have basically three categories of pore types: 1) Rounded or spherical pores, representing the moldic, vug or intraparticle porosities; 2) intercrystalline interparticle porosity and 3) fractured pores (cracks) or microporosity characterized by the occurrence of microfractures and channels. To develop rock physical models it is necessary: 1) to characterize and classify pore geometry; 2) to define the multipore system for the Kuster-Toksöz model, in order to take into account pore geometry combinations; 3 ) to calculate $V_{P}$ and $V_{S}$ based on incompressibility $(K)$ and shear $(\mu)$ moduli, and density $(\rho)$ for different fluid saturation conditions.

\section{VACUUM FIELD - GLORIETA-PADDOCK RESERVOIR}

Figure 1 shows the geological map of the study site. The Vacuum field in New Mexico, discovered in 1929, has a sedimentary section composed mainly of Paleozoic carbonates and evaporites, including the Permian dolomites of the Grayburg and San Andres formations and the Glorieta and Paddock Formations, which define the Glorieta-Paddock carbonate reservoir (Acuna, 2000). Figure 2 shows the stratigraphic column of the Delaware Basin, where the Vacuum Field and the Permian provinces are located.

The Glorieta Formation is characterized by dolomitic sandstones naturally fractured, with porous isolated lenses. The Paddock Formation is divided into low Lr and Upper units. The Upper Paddock Formation is composed by dolomites with intercrystalline and vug porosities and limestones with vug and moldic porosities occurring at regular intervals, forming the primary production zone. The Lower Paddock Formation shows naturally fractured dolomites. Figure 3 shows rock samples of the Glorieta and Paddock formations (Acuna, 2000). This study focuses on the formations of the Glorieta-Paddock carbonate reservoir.

\section{Glorieta-Paddock Reservoir Data Selection}

Average elastic and petrophysical properties were estimated for each reservoir-layer, using core samples from five wells located in the Chevron-Texaco concession area (Fig. 1-B). The following 


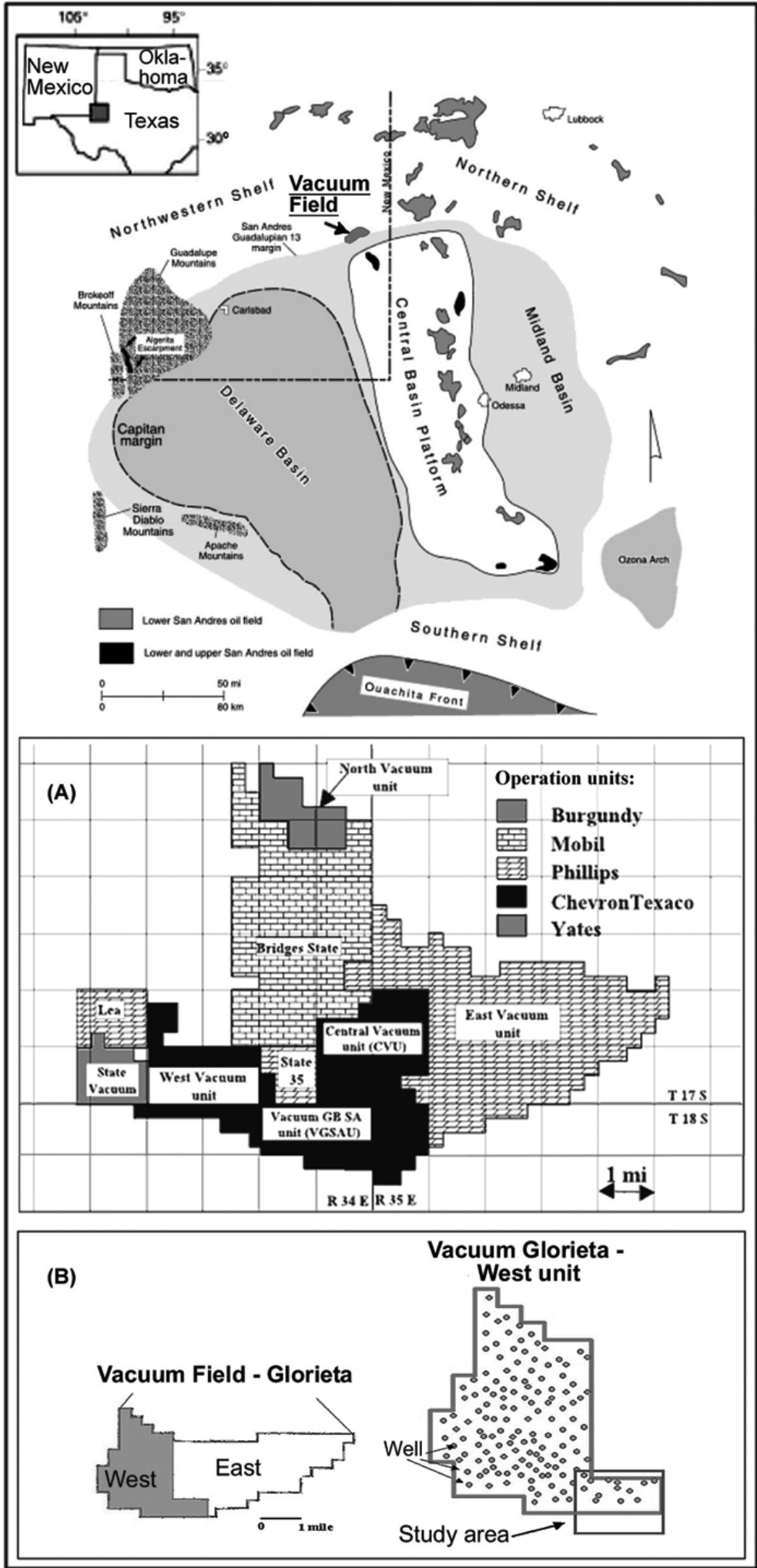

Figure 1 - Map showing Vacuum field and Permian provinces: (A) companies operating in Vacuum field; (B) west unit in detail - study site in rectangle, Vacuum field - Glorieta, operated by Chevron-Texaco since 1992. Adapted from Acuna (2000) and Grammer et al. (2004). 


\begin{tabular}{|c|c|c|c|c|c|c|c|c|}
\hline ERA & PERIOD & EPOCH & \multicolumn{3}{|c|}{ FORMATION } & LITHOLOGY & $\begin{array}{c}\text { THICKNESS } \\
(\mathrm{m})\end{array}$ & $\begin{array}{c}\text { DEPTH } \\
(\mathrm{m})\end{array}$ \\
\hline \multirow{17}{*}{$\begin{array}{l}\frac{U}{0} \\
0 \\
\frac{0}{\pi} \\
\frac{0}{0}\end{array}$} & \multirow{17}{*}{ 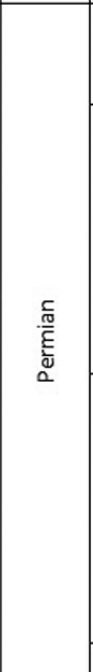 } & \multirow{3}{*}{ Ochoan } & \multicolumn{3}{|c|}{ Dewey Lake } & Redbeds / Anhydrite & $60-125$ & 125 \\
\hline & & & \multicolumn{3}{|c|}{ Rustler } & Halite & 31 & 156 \\
\hline & & & \multicolumn{3}{|c|}{ Salado } & Halite / Anhydrite & 305 & 461 \\
\hline & & \multirow{6}{*}{ Guadalupian } & \multicolumn{3}{|c|}{ Tansill } & Anhydrite / Dolomite & 61 & 522 \\
\hline & & & \multicolumn{3}{|c|}{ Yates } & Sandstone - Shale / Anhydrite & 61 & 583 \\
\hline & & & \multicolumn{3}{|c|}{ Seven Rivers } & Dolomite / Anhydrite & 152 & 735 \\
\hline & & & \multicolumn{3}{|c|}{ Queen } & $\begin{array}{c}\text { Sandy Dolomite / Anhydrite / } \\
\text { Shale }\end{array}$ & $65-155$ & 890 \\
\hline & & & \multicolumn{3}{|c|}{ Grayburg } & $\begin{array}{c}\text { Dolomite / Anhydrite / Shale / } \\
\text { Sandstone }\end{array}$ & 92 & 982 \\
\hline & & & \multicolumn{3}{|c|}{ San Andres } & Dolomite / Anhydrite & 460 & 1442 \\
\hline & & \multirow{7}{*}{ Leonardian } & \multicolumn{3}{|c|}{ Glorieta } & Sandy Dolomite & 30 & 1472 \\
\hline & & & \multirow{5}{*}{$\stackrel{\circ}{\searrow}$} & Paddock & Upper & Limestone / Dolomite & \multirow{2}{*}{92} & \multirow{2}{*}{1564} \\
\hline & & & & Paddock & Lower & Dolomite & & \\
\hline & & & & \multicolumn{2}{|c|}{ Blinebry } & Dolomite / Sandy Dolomite & 305 & 1869 \\
\hline & & & & \multicolumn{2}{|c|}{ Tubb } & Dolomite / Sandy interval & 122 & 122 \\
\hline & & & & \multicolumn{2}{|c|}{ Drinkard } & Dolomite & 92 & 1961 \\
\hline & & & \multicolumn{3}{|c|}{ Abo } & Dolomite / Anhydrite / Shale & 305 & 427 \\
\hline & & Wolfcampian & \multicolumn{3}{|c|}{ Wolfcamp } & Limestone / Dolomite & $0-460$ & 2421 \\
\hline
\end{tabular}

Figure 2 - Stratigraphic column of the Delaware Basin, where the Vacuum field and the Permian provinces are found. The Glorieta-Paddock reservoir study site is highlighted. Adapted from Acuna (2000).

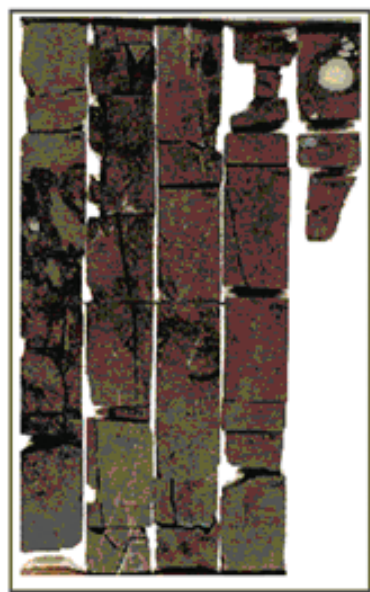

(B)

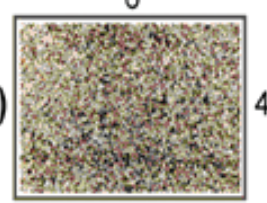

$4^{\prime \prime}$

Lower Glorieta: Sandy Dolomite
$\phi=5.0 \%, \kappa=0.07 \mathrm{mD}$
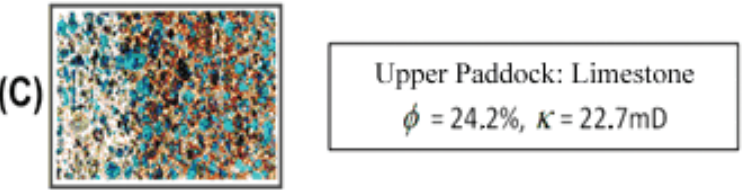

(D)

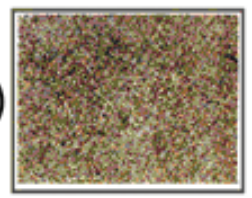

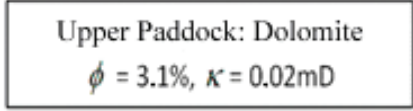

(A)

Figure 3 - Rock core photos of the Glorieta-Paddock reservoir: (A) Shows the fractures in a core of the Lower Paddock Dolomite; (B) dolomitic sand of the Lower Paddock Formation; (C) porous limestone (in blue) and permeability of the production area in the Upper Paddock Formation; (D) dolomite of the Upper Paddock, showing low porosity and permeability, characteristics of a not very good production area. Adapted from Acuna (2000).

formations were highlighted: Glorieta - dolomite, Upper Paddock - limestone and Lower Paddock - dolomite. Figure 4 shows the ideal vertical petrophysical profiles for the average mineralogical composition (Acuna, 2000), and Figure 5 shows the vertical petrophysical profiles calculated according to Nur et al. (1995), to characterize the framework for both dry and drained rocks.
Table 4 shows calcite and dolomite properties, the minerals most commonly found in carbonates; however, other minerals are also observed in the Glorieta and Paddock formations, justifying the average petrophysical values listed in Figure 4. The selected data will be used to implement the rock physics relationship with the estimate of seismic velocity under fluid saturation. 


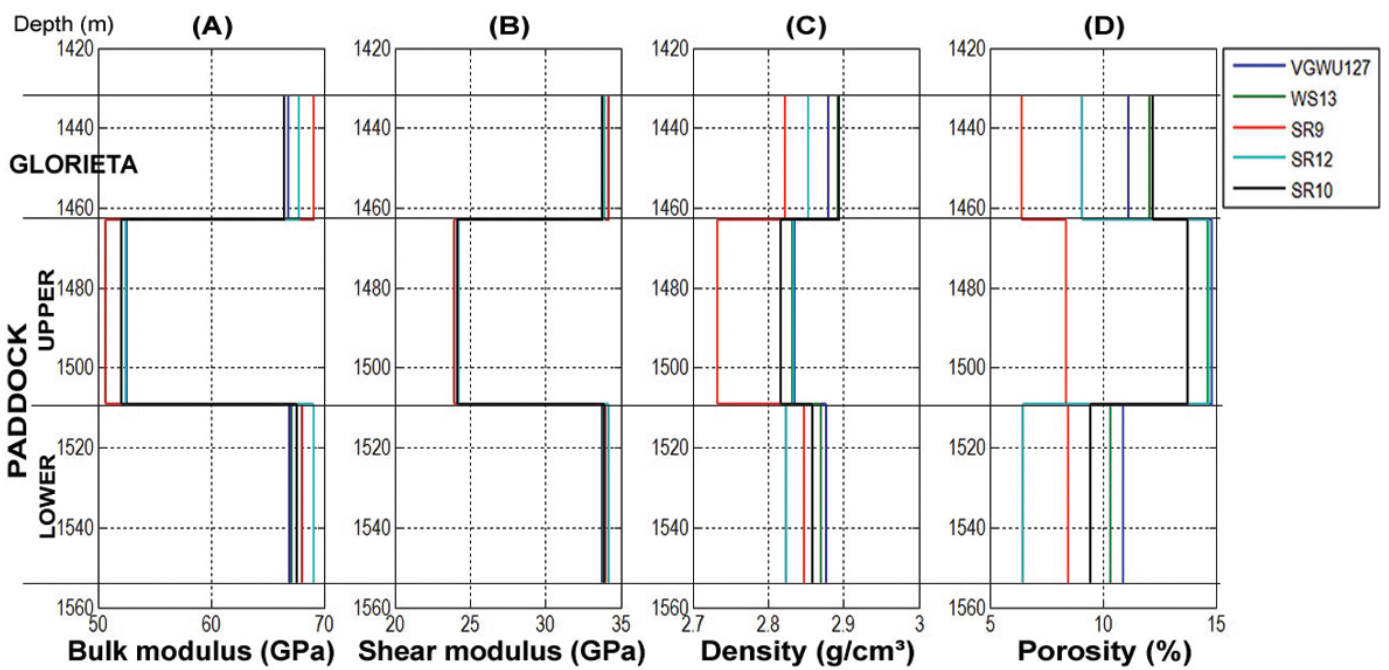

Figure 4 - Elastic and petrophysical properties according to profile data of 5 wells (Acuna, 2000), highlighting the mineralogical averages of Glorieta and Paddock formations: (A) mineral incompressibility modulus, (B) mineral shear modulus, (C) mineral density, and (D) porosity.

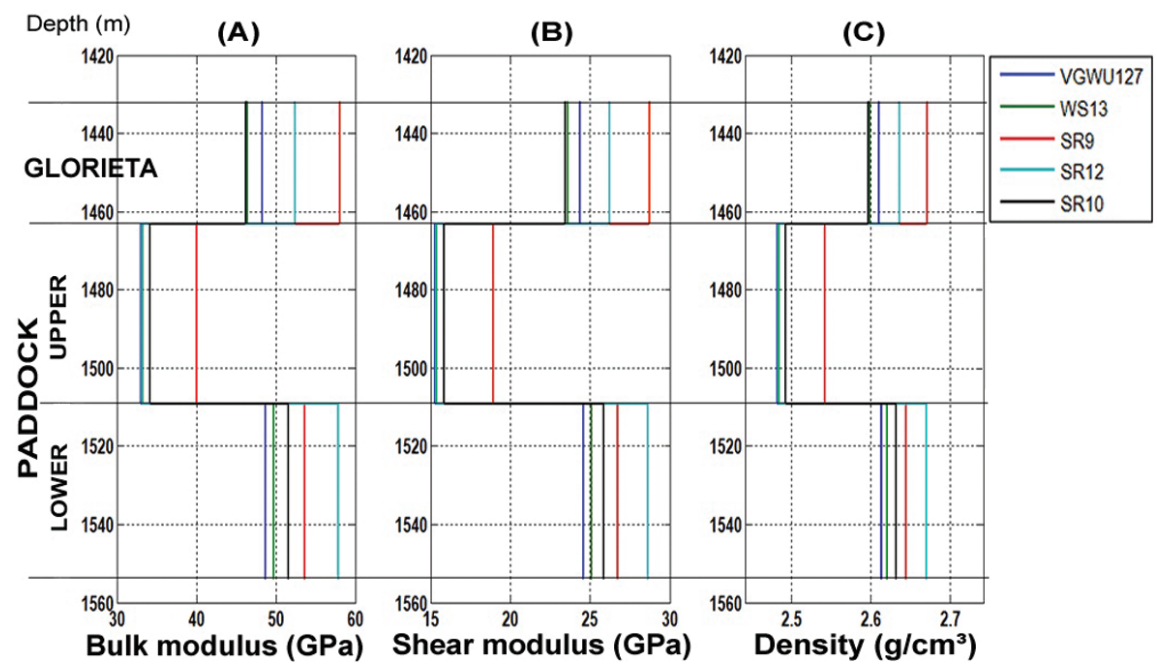

Figure 5 - Calculation of framework elastic properties (drained or dry rocks) for the Glorieta and Paddock formations, according to Nur et al. (1995), based on the data profile of 5 wells (Acuna, 2000): (A) incompressibility modulus, (B) shear modulus, and (C) density.

\section{FORMATION OF CARBONATE VERSUS SILICICLASTIC ROCKS}

The formation of carbonate sedimentary rocks is influenced by physical processes dominated by complex biological and diagenetic processes that do not occur in siliciclastic rocks. The generation of siliciclastic sediments is related to the intensity and type of physical energy, such as winds, waves, direction and intensity of currents, which affect sediment texture on the depositional site (Folk, 1968). On the other hand, the generation of carbonate sediments is affected by the organism population dynamics and derived particles, as well as particularities of the organism microstructure (Moore, 1989).

The texture of the carbonates is dependent on the diagenetic process that generates different porosity types of carbonate rocks (Moore, 1989) and are generally classified according to two schemes: Folk (1959) and Dunham (1962). Rock porosity represents the volume fraction that is not occupied by solids, an important parameter to estimate hydrocarbon storage capacity. Therefore, total porosity represents the volume of voids, connected or not, while effective porosity corresponds to the volume of connected pores, controlling where fluid is allowed to flow. 
Table 1 - Comparison between carbonate and siliciclastic sedimentary rocks. Adapted from Moore (1989).

\begin{tabular}{|c|c|}
\hline Carbonate sedimentary rocks & Siliciclastic sedimentary rocks \\
\hline Higher occurrence in the tropics & Climate, water depth are not limiting \\
\hline Most marine & Marine or non-marine \\
\hline Standing structure bodies & There is no analogous procedure \\
\hline $\begin{array}{l}\text { Sediment texture is controlled by growth and ultra-structure of } \\
\text { the bodies. }\end{array}$ & $\begin{array}{l}\text { Sediment texture reflects the hydraulic energy of sedimentation } \\
\text { environment }\end{array}$ \\
\hline Grain composition directly reflects deposition environment & $\begin{array}{l}\text { Grain composition reflects origin of sediment, climate and } \\
\text { tectonic of the source }\end{array}$ \\
\hline $\begin{array}{l}\text { Limestone shelves frequently consist of numerous stacked } \\
\text { sequences }\end{array}$ & Clastic shelves generally show no cyclicity \\
\hline $\begin{array}{l}\text { Shelf is affected by sea level changes due to carbonate production } \\
\text { rate constant in the entire shelf }\end{array}$ & $\begin{array}{l}\text { Shelf evolution responds to sea level in a more complex manner } \\
\text { due to source tectonics and climate }\end{array}$ \\
\hline Often cemented in marine environment & Rarely cemented in marine environment \\
\hline Mud and grains may be formed by chemical precipitation & $\begin{array}{l}\text { Mud and grains are formed by the degradation of pre-existing } \\
\text { rocks }\end{array}$ \\
\hline $\begin{array}{l}\text { Susceptible to distortions in early diagenesis, porosity difficult } \\
\text { to predict }\end{array}$ & $\begin{array}{l}\text { Less susceptible to early diagenesis, predictable porosity related } \\
\text { to depositional environment }\end{array}$ \\
\hline $\begin{array}{l}\text { More susceptible to diagenesis by burial, higher porosity on the } \\
\text { surface }\end{array}$ & $\begin{array}{l}\text { Less susceptible to diagenesis by burial, porosities relative to } \\
\text { deeper layers }\end{array}$ \\
\hline
\end{tabular}

In sedimentary rocks, the porosity formed during deposition process is called primary porosity, while porosity generated after the deposition process, caused by geochemical events such as dissolution, is referred to as secondary porosity (Suguio, 1998; Escobar Chaparro, 2002). The occurrence of fractures is common in carbonate rocks in response to the tension generated by three main regimes: tectonics, geopressure and formation of caves by dissolution, which can be good for the exploration of hydrocarbon reserves due to porosity variation (Escobar Chaparro, 2002).

According to Moore (1989), the diagenesis in carbonates is affected by temperature and the chemical reactions occurring in the pore fluids, such as dissolved organic acids, carbon dioxide $\left(\mathrm{CO}_{2}\right)$, hydrogen sulfide $\left(\mathrm{H}_{2} \mathrm{~S}\right)$, among other components released during mineral phase change, and thermal degradation of organic matter and hydrocarbon. Thus, carbonates are more susceptible to dissolution due to the high rate of chemical reactions during diagenesis, which changes drastically the resulting porosity. Under burial, the carbonates react to pressure more easily than siliciclastics, causing a porosity decrease with depth. Lower rates of chemical reactions in the siliciclastics, are usually inherent to unstable siliciclastic phases, such as feldspars, causing secondary porosity formation. According to Spadini \& Marçal (2005) anomalies in carbonate reservoirs can occur even under great burial pressure, thus maintaining good porosity levels by physical-chemical processes. The basic differences between siliciclastic and carbonate rocks are summarized in Table 1.

\section{CHARACTERIZATION AND CLASSIFICATION OF PORE GEOMETRY IN CARBONATES}

Carbonate texture is related to diagenetic processes, which induces the formation of different pore types in the carbonate rocks (Moore, 1989). Usually, the texture of carbonates is classified according to the schemes proposed by Folk (1959) and Dunham (1962). In addition, Suguio (1998) also defines carbonate rock porosities, such as:

- interparticle porosity between sedimentary particles;

- intraparticle porosity resulting from the voids within individual crystals;

- microfractures or microcracks porosity results from fractured surfaces, which is given by the percentage of open fractures relative to the total rock volume;

- channel porosity results from dissolution along the fractures or other types of elongated pores;

- moldic or shaped porosity is defined by the voids formed by selective removal, typically by dissolution of components, such as shells and oolites;

- vug porosity is caused by the dissolution of dolomite or calcite crystals in the recrystallization process. 
The Kuster-Toksöz model assumes pore geometry of carbonate rock beforehand. Thus, taking into consideration the definitions proposed by Suguio (1998), an ideal classification of pore type was adopted based on Kumar \& Han (2005), Xu \& Payne (2009) and Wang \& Sun (2010) in order to analyze the input data of the Glorieta and Paddock Formations (Figs. 4 and 5). Basically, these authors suggest three classes for porosity volume in clean carbonates, with possible variations among the types: 1) round or spherical pores represent moldic, vug or intraparticle porosity; 2) intercrystalline, interparticle porosity; and 3) cracks or microporosity formed by secondary processes generating microfractures or microcracks and channels in low porosity carbonates. It is assumed as reference, for carbonate rocks, the occurrence of interparticle pores, either presenting rounded pores resulting in stiffer rocks, or with fractured microporosity resulting in less stiff rocks. The average pore heterogeneity shown in Figure 6 is expressed by the statistical distribution of pore shape coefficients. The pore geometry coefficient is given by the ratio between the small and the great semi-axis, which is 1 for a perfect spherical geometry and tends to 0 (zero) for a more ellipsoidal geometry. Table 2 shows average pore geometry coefficient adopted for the carbonate rocks of this study.

Table 2 - Pore geometry coefficient adopted for carbonates, according to Xu \& Payne (2009).

\begin{tabular}{|c|c|}
\hline $\begin{array}{c}\text { Pore } \\
\text { composition }\end{array}$ & $\begin{array}{c}\text { Pore geometry } \\
\text { coefficient }(\alpha)\end{array}$ \\
\hline Round & 0.80 \\
Interparticle & 0.15 \\
Fractured & 0.02 \\
\hline
\end{tabular}

Figure 7 shows in detail the variations caused by pore geometry in relation to pore volume. The crossplot $V_{P}-\phi$ (porosity) shows the Glorieta-Paddock data, calculated for drained rocks. A good correspondence with the lithological descriptions presented in Table 3 is observed. Kumar \& Han (2005) emphasize that the predominantly spherical pore type approaches Hashin-Shtrikman lower limit. The interparticle pore geometry is regarded as reference in the study of carbonates, and may be affected by microfractures or spherical inclusions in the pore volume.

\section{Kuster-Toksöz model: pore geometry combinations}

To calculate $V_{P}$ and $V_{S}$, Kuster \& Toksöz (1974) derived expressions under ultrasonic frequency conditions to estimate the incompressibility $\left(K_{K T}\right)$ and shear $\left(\mu_{K T}\right)$ moduli. Berryman (1995) included pore geometry contribution in the Kuster-Toksöz model, according to:

$$
\begin{gathered}
K_{K T}=\frac{\frac{4}{3} \mu_{m} K_{\phi}+K_{m}\left(K_{m}+\frac{4}{3} \mu_{m}\right)}{K_{m}+\frac{4}{3} \mu_{m}-K_{\phi}}, \\
\mu_{K T}=\frac{\mu_{\phi} \zeta_{m}+\mu_{m}\left(\mu_{m}+\zeta_{m}\right)}{\mu_{m}+\zeta_{m}-\mu_{\phi}},
\end{gathered}
$$

where $K_{m}$ and $\mu_{m}$ are the incompressibility and shear moduli of the mineral matrix, respectively. The empirical parameter $\zeta_{m}$ may be calculated according to Berryman (1995):

$$
\zeta_{m}=\frac{\mu_{m}\left(9 K_{m}+8 \mu_{m}\right)}{6\left(K_{m}+2 \mu_{m}\right)} .
$$

Pore type and fluid saturation are expressed as inclusions in:

$$
\begin{gathered}
K_{\phi}=\sum_{i=1}^{N} \phi_{i}\left(K_{i}-K_{m}\right) P^{m i}, \\
\mu_{\phi}=\sum_{i=1}^{N} \phi_{i}\left(\mu_{i}-\mu_{m}\right) Q^{m i} .
\end{gathered}
$$

According to Berryman (1995), and based on pore shape, the parameters $P^{m i}$ and $Q^{m i}$ are estimated for each material phase $i$, inclusion of total $N$, in the pore volume $\phi_{i}$. Then, the parameters $K_{\phi}$ and $\mu_{\phi}$ are rewritten to represent a system of multiple pore geometries:

$$
\begin{gathered}
K_{\phi} f_{E} \sum_{i=1}^{N} \phi_{i}\left(K_{i}-K_{m}\right) P_{E}^{m i}+f_{I} \sum_{i=1}^{N} \phi_{i}\left(K_{i}-K_{m}\right) P_{I}^{m i} \\
+f_{F} \sum_{i=1}^{N} \phi_{i}\left(K_{i}-K_{m}\right) P_{F}^{m i} \\
\mu_{\phi} f_{E} \sum_{i=1}^{N} \phi_{i}\left(\mu_{i}-\mu_{m}\right) Q_{E}^{m i}+f_{I} \sum_{i=1}^{N} \phi_{i}\left(\mu_{i}-\mu_{m}\right) Q_{I}^{m i} \\
+f_{F} \sum_{i=1}^{N} \phi_{i}\left(\mu_{i}-\mu_{m}\right) Q_{F}^{m i},
\end{gathered}
$$

where $f_{E}, f_{I}$ and $f_{F}$ are the fractions for pore types or shapes: spherical, interparticle and microfractures, respectively.

\section{ESTIMATES OF SEISMIC VELOCITIES}

Based on the calculation of $K$ and $\mu$ moduli, combined with rock density $(\rho)$, it is possible to estimate $V_{P}$ and $V_{S}$, as obtained by Mavko et al. (1998):

$$
\begin{gathered}
V_{P}=\sqrt{\frac{K+\frac{4}{3} \mu}{\rho},} \\
V_{S}=\sqrt{\frac{\mu}{\rho}} .
\end{gathered}
$$




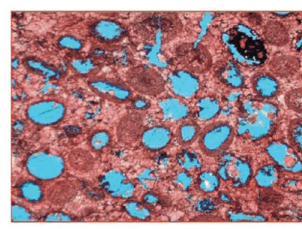

$V p>V p \_R e f$

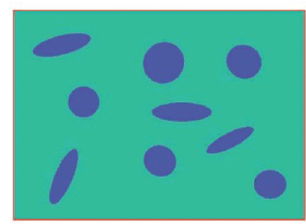

Ref t round

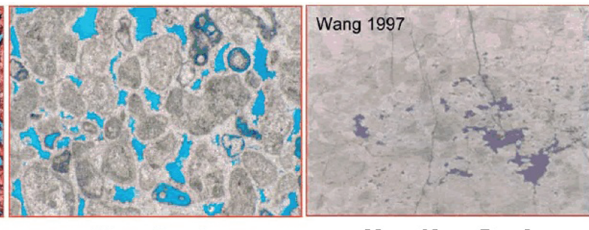

$V p_{-}$Ref

$V p<V p_{-} R e f$

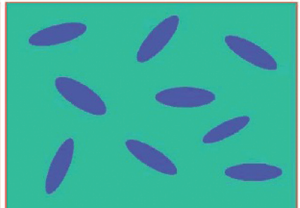

Reference

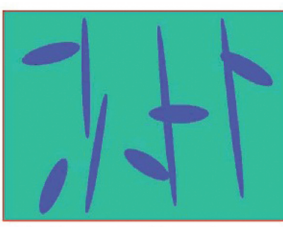

Reftmicrofractures

Figure $\mathbf{6}$ - Illustration showing carbonate pore geometry. Reference for interparticle pores. Adapted from Xu \& Payne (2009) and Wang (1997).

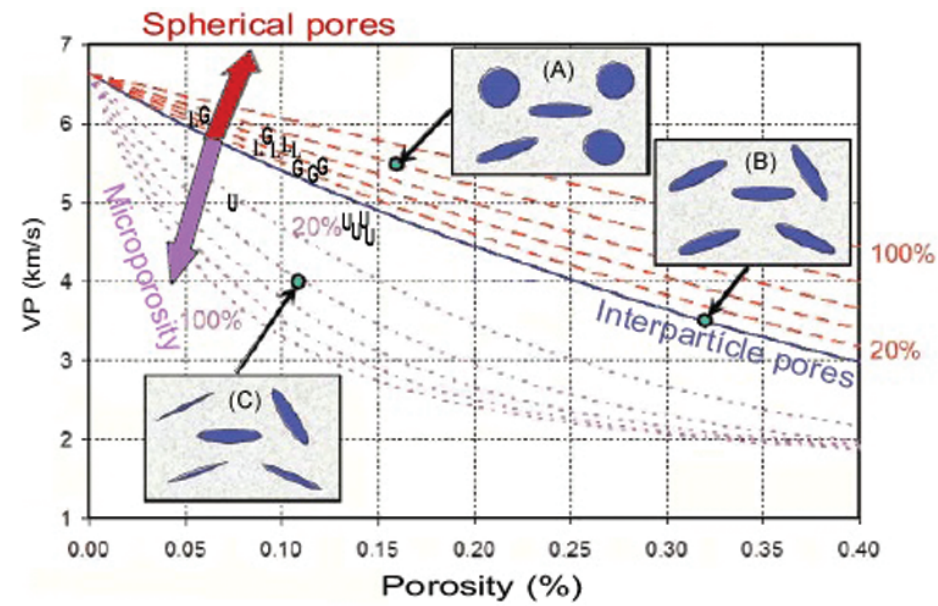

Figure 7 - Diagram used to determine carbonate pore types. The red arrow indicates increasing round pores; the purple arrow indicates increasing fractures and microporosity. The blue line is the reference for interparticle pore (Kumar \& Han (2005) and Xu \& Payne (2009)). The G, U and L points were calculated for drained rocks of Glorieta, Upper and Lower Paddock intervals, respectively. Note the ideal porous type: (A) $80 \%$ round, (B) interparticle reference, and (C) $40 \%$ microfractures.

The fluid has zero shear modulus, therefore $\mu$ is the same for dry and fluid saturated rock, determined by laboratory tests or well profile analysis. On the other hand, $K$ and $\rho$ are influenced by saturating fluid for different phases, where:

$$
\rho=\rho_{0}(1-\phi)+\rho_{f l} \phi,
$$

is the relationship of mineral density $\left(\rho_{0}\right)$, fluid density $\left(\rho_{f l}\right)$ and $(\phi)$; therefore, $\rho_{f l}$ dependent on fluid phases and their ratios. Table 4 shows fluid parameters adopted and the properties of the main minerals commonly found in carbonate rocks. The mean values of the mineral properties used in this study (Table 4) are the values of the characterization profile by Acuna (2000).
Incompressibility $(K)$ and shear $(\mu)$ moduli of carbonate rocks can be estimated and evaluated according to Kuster-Toksöz model, Equations (1) and (2), or by Gassmann theory (1951):

$$
\begin{gathered}
K_{\text {Sat }}=K_{d r y}+\frac{\left(1-\frac{K_{d r y}}{K_{0}}\right)^{2}}{\frac{\phi}{K_{f l}}+\frac{1-\phi}{K_{0}}-\frac{K_{d r y}}{K_{0}^{2}}}, \\
\mu_{\text {Sat }}=\mu_{d r y},
\end{gathered}
$$

where $K_{\text {Sat }}$ is the incompressibility modulus of saturated rock, $K_{0}$ is the mineral incompressibility modulus of the matrix components, estimated by laboratory tests or well logs, $K_{f l}$ is the fluid incompressibility modulus. Dry rock or framework incom- 
Table 3 - Pore shape effect on data distribution of the wells with respect to reference line. Interparticle: Glorieta formation, round; Upper Paddock, fractured; and Lower Paddock, round.

\begin{tabular}{|c|c|c|c|}
\hline & Well & Formation & $\begin{array}{c}\text { Poreshape influence } \\
\text { (interparticle reference) }\end{array}$ \\
\hline & & & $A$-round ; $F$-fractured \\
\hline \multirow[t]{3}{*}{ VGWU127 } & \multicolumn{2}{|c|}{ Glorieta } & \multirow{3}{*}{$\begin{array}{l}20 \%-A \\
10 \%-F \\
40 \%-A\end{array}$} \\
\hline & Paddock & Upper & \\
\hline & & Lower & \\
\hline \multirow[t]{3}{*}{ WS-13 } & \multicolumn{2}{|c|}{ Glorieta } & \multirow{3}{*}{$\begin{array}{l}20 \%-A \\
10 \%-F \\
40 \%-A\end{array}$} \\
\hline & Paddock & Upper & \\
\hline & & Lower & \\
\hline \multirow[t]{3}{*}{ SR-9 } & \multicolumn{2}{|c|}{ Glorieta } & \multirow{3}{*}{$\begin{array}{l}40 \%-A \\
20 \%-F \\
20 \%-A\end{array}$} \\
\hline & Paddock & Upper & \\
\hline & & Lower & \\
\hline \multirow[t]{3}{*}{ SR-12 } & \multicolumn{2}{|c|}{ Glorieta } & \multirow{3}{*}{$\begin{array}{l}40 \%-A \\
10 \%-F \\
20 \%-A\end{array}$} \\
\hline & Paddock & Upper & \\
\hline & & Lower & \\
\hline \multirow[t]{3}{*}{ SR-10 } & \multicolumn{2}{|c|}{ Glorieta } & $20 \%-A$ \\
\hline & Paddock & Upper & $10 \%-F$ \\
\hline & & Lower & $20 \%-A$ \\
\hline
\end{tabular}

pressibility modulus $\left(K_{d r y}\right)$ and dry rock shear modulus $\left(\mu_{d r y}\right)$ may be obtained using the relationship proposed by Nur et al. (1995) for $0 \leq \phi \leq \phi_{C}$, where, $\phi_{C}$ is rock critical porosity, that is, the limiting porosity that a rock can have, since above this value the rock becomes loose sediments.

\section{Incompressibility of fluid-saturated rock}

Fluid incompressibility modulus is calculated according to fluid saturation model, and may be homogeneous or heterogeneous for brine, oil and gas phases (Mavko et al., 1998). In this study, we considered homogeneous saturation for the ideal situations: $100 \%$ brine, $100 \%$ oil and $100 \%$ gas, according to the properties shown in Table 4.

Table 4 - Elastic properties of minerals and fluids, according to Mavko et al. (1998) and Walls \& Dvorkin (2005).

\begin{tabular}{|l|c|c|c|c|}
\hline & & $K(G P a)$ & $\mu(G P a)$ & $\rho(g / c c)$ \\
\hline \multirow{2}{*}{ Minerals $^{*}$} & Calcite & 70.2 & 29 & 2.71 \\
\cline { 2 - 5 } & Dolomite & 76.4 & 49.7 & 2.87 \\
\hline \multirow{3}{*}{ Fluids $^{* *}$} & Brine & 2.68 & & 1.03 \\
\cline { 2 - 5 } & Oil & 0.820 & & 0.782 \\
\cline { 2 - 5 } & Gas (Ethane) & 0.135 & & 0.341 \\
\hline
\end{tabular}

*Mavko et al. (1998); **Walls \& Dvorkin (2005).
The formation of an effective fluid from different phases can be estimated from the Voigt-Reuss-Hill average, using the estimated fluid saturation properties, according to Batzle \& Wang (1992) to estimate the changes occurring in the reservoir with respect to temperature and pressure conditions. Xu \& Payne (2009) suggest a formula to replace fluids in carbonates, which uses the Voigt-Reuss-Hill average to estimate the elastic modulus using the Kuster-Toksöz model and the Gassmann theory.

\section{RESULTS}

The results obtained for $V_{P}$ and $V_{S}$ using the Glorieta-Paddock data are presented and show the sensitivity of these velocities to the imposed saturation conditions. In this study, the potential response of each reservoir layer was evaluated under saturation conditions, followed by a discussion. As shown in Figures 8 to 12 and as initially suggested in the definition of the study site, the Upper Paddock Formation has a greater potential to predict the saturating fluid.

In Figure 8, the crossplot between the incompressibility modulus of the rock saturated by fluid estimated by Kuster-Toksöz $\left(K_{K T}\right)$ and for drained rock $\left(K_{d r y}\right)$ shows the greater potential of the Upper Paddock Formation to reflect changes in the saturation conditions. It should be noted that the drained and saturated 


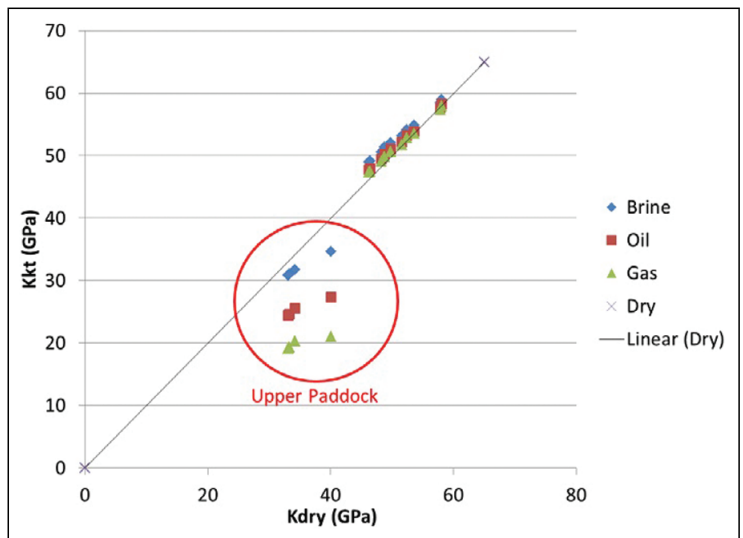

Figure 8 - Crossplot of incompressibility modulus of fluid saturated $\left(K_{K T}\right)$ and drained $\left(K_{d r y}\right)$ rocks according to Kuster-Toksöz model. Upper Paddock cores are highlighted for displaying significant sensitivity to saturation.

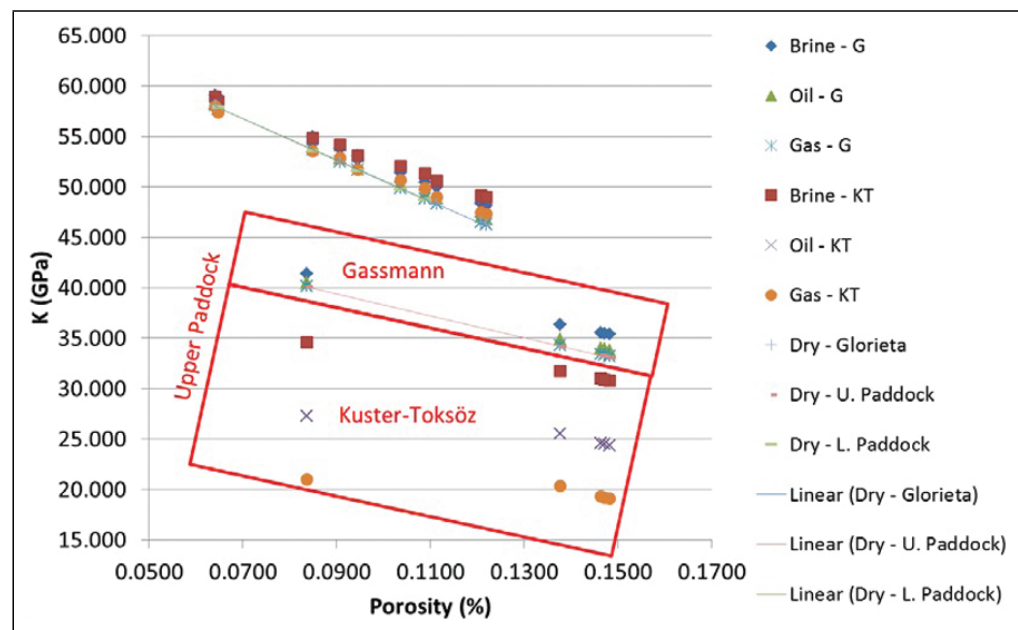

Figure $\mathbf{9}$ - Crossplot $K-\phi$ of Kuster-Toksöz and Gassmann models for identical saturation situations, to verify potential variation in the Glorieta-Paddock reservoir. Highlight shows Upper Paddock formation.

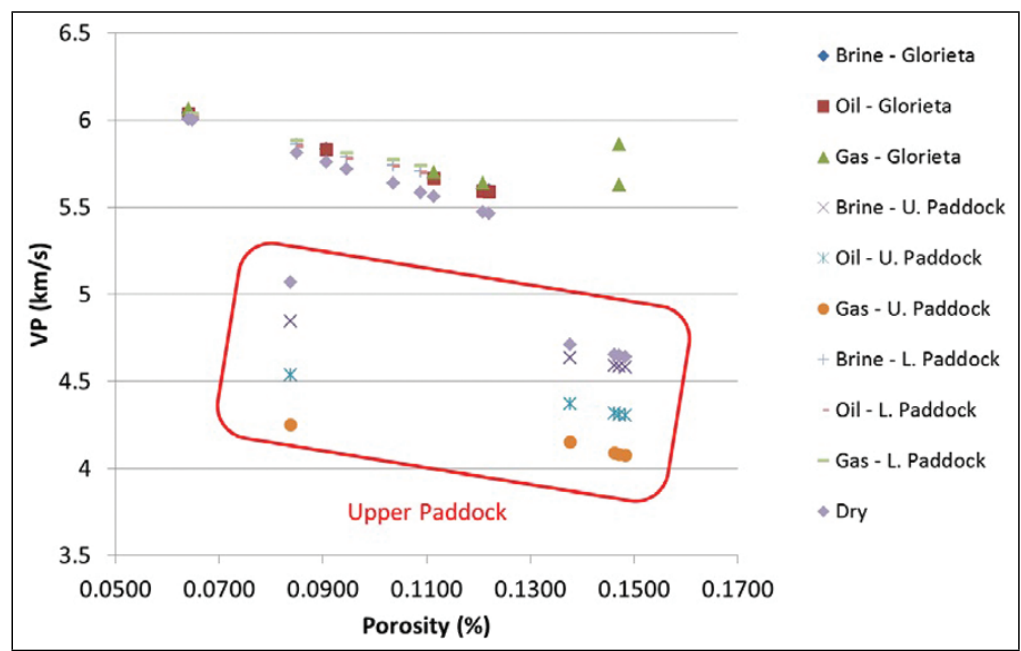

Figure 10 - Crossplot $V_{P}-\phi$ for different saturation situations according to Kuster-Toksöz model highlighting the Upper Paddock Formation. 


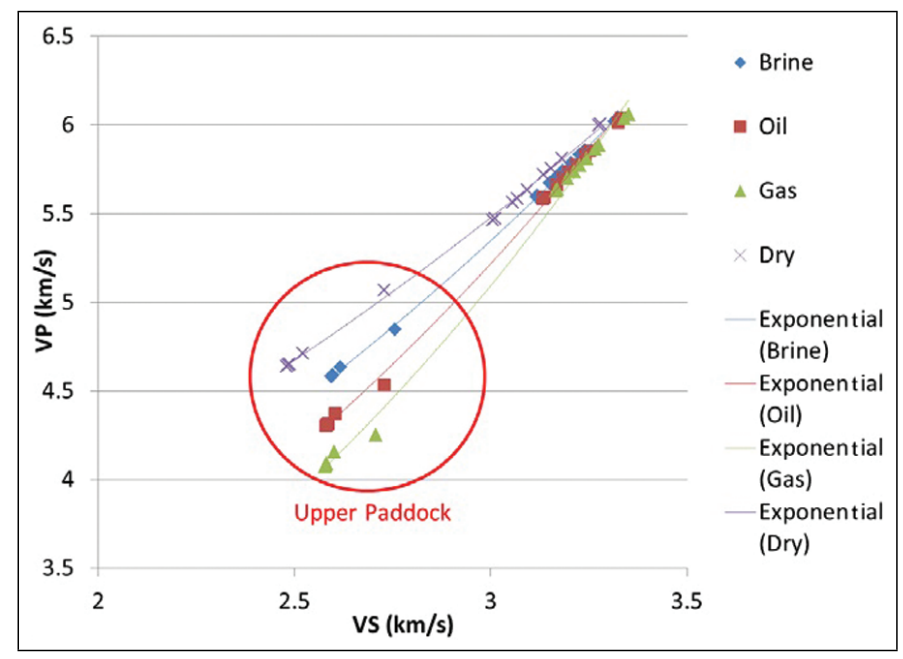

Figure 11 - Crossplot $V_{P}-V_{S}$ for different saturation situations according to Kuster-Toksöz model highlighting the non-linear trend of carbonates, as shown by Castagna et al. (1993).

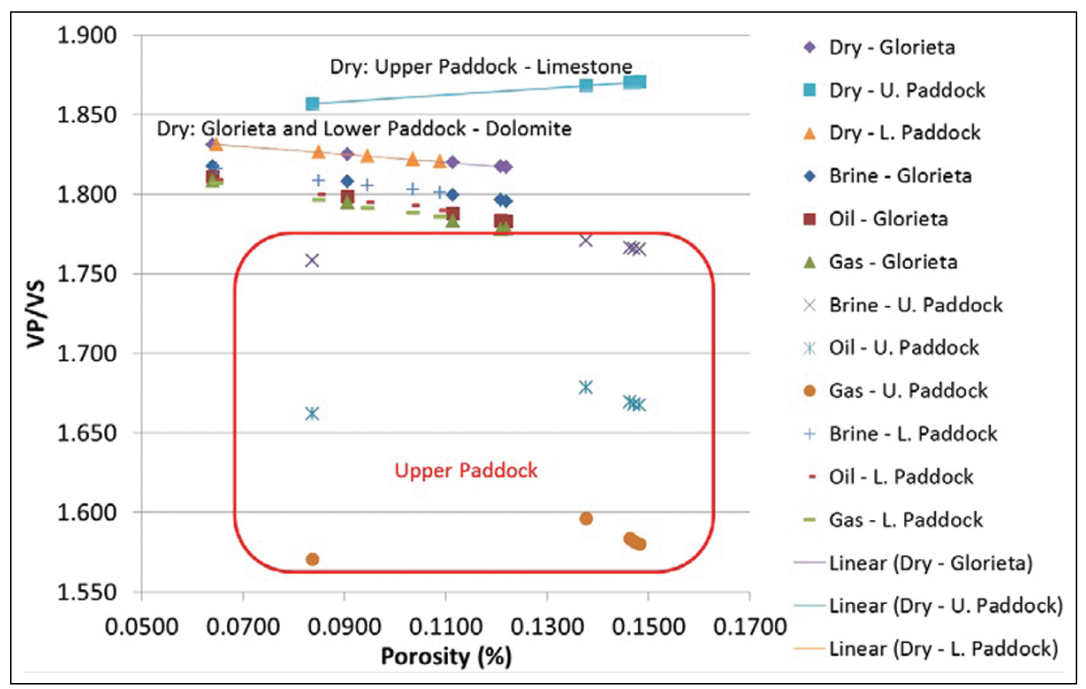

Figure 12 - Crossplot $V_{P} / V_{S}-\phi$ for different saturation and dry (drained) rocks according to Kuster-Toksöz model highlighting the saturation changes of the Upper Paddock. It is possible to distinguish the lithologies as stated by Castagna et al. (1993).

incompressibility moduli of Glorieta and Lower Paddock formations remained practically unchanged. Figure 9 shows the crossplot $K-\phi$ for identical saturation conditions, in order to enable the investigation regarding the sensitivity of incompressibility modulus of the saturated rock $(K)$, estimated by Gassmann and Kuster-Toksöz; and, potential variation in the Glorieta-Paddock reservoir. The Upper Paddock Formation has greater capacity to distinguish different fluid phases as a function of its porosity types, and also, because it has lower incompressibility values. In addition, Figure 9 shows that the Kuster-Toksöz estimated incompressibility has higher differentiation capacity compared to Gassmann theory. Such behavior was expected because the Kuster-Toksöz model takes into consideration pore geometry. It should also be highlighted that the Upper Paddock Formation has interparticle porosity affected by fracturing, which results in micropores. The rock becomes less rigid and shows lower incompressibility values, thus reflecting increased seismic sensitivity. On the other hand, the opposite is observed for the Glorieta and Lower Paddock formations with spherical interparticle pore geometries (Table 3); therefore, the rock is more rigid, incompressibility higher and seismic sensitivity lower. Applying the modulus estimated from the Kuster-Toksöz model, $\left(V_{P}\right)$ was calculated for 
the Upper Paddock Formation (Fig. 9), as shown in the crossplot $V_{P}-\phi$ of Figure 10, demonstrating the elevated potential to distinct between saturation phases.

Figure 11 shows the crossplot between $V_{P}$ and $V_{S}$, for drained and saturated rocks with different fluids, estimated by Kuster-Toksöz. It is interesting to observe the non-linear trend of the curves, typical for carbonates, according to Castagna et al. (1993) who suggest the influence of heterogeneity on pore geometry. Differently, for siliciclastic rocks a linear trend is observed due to the presence of predominantly homogeneous pores.

Figure 12 shows the crossplot $V_{P} / V_{S}-\phi$ according to Kuster-Toksöz, for drained rocks and for each saturated fluid phase, established in Table 4. According to Castagna et al. (1993), this analysis is useful to distinguish areas where there is fluid variation and different lithology. Hence, this case study shows the potential of Upper Paddock Formation to reflect saturation changes. To differentiate carbonate lithologies in drained situations, the variation occurs according to mineralogical composition, the average value for dolomite is 1.7 and for calcite 1.9. This confirms the expected correlation for Glorieta-Paddock reservoir in this interval, specifically the Upper Paddock Formation, limestone; and Glorieta and Lower Paddock, dolomites; as a function of mean elastic and petrophysical properties for the minerals that make up each layer, as shown in Figure 4.

\section{CONCLUSIONS}

This case study implements a methodology to classify and analyze pore geometry in carbonate reservoirs, in order to define a system of multiple pore geometries as required by Kuster-Toksöz model. This allowed us to directly estimate incompressibility and shear moduli for rocks, under both homogeneous saturation by the fluids, brine, oil and gas, and drained conditions.

This methodology applied to the study site, Glorieta-Paddock reservoir, proved that the Upper Paddock Formation is potentially more capable of storing fluids, and has higher seismic sensitivity. It was also verified that the interparticle porosity, with microfractures pore geometry in the Upper Paddock Formation, resulted in lower rock incompressibility and rigidity, which enhances the seismic sensitivity to saturation. Unlike other formations, Glorieta and Lower Paddock interparticle porosity characterized by spherical geometry results in lower incompressibility and rock rigidity, and reduced seismic sensitivity. Therefore, the results from Kuster-Toksöz and Gassmann models were compared. Gassmann results are similar to those presented by Acuna (2000), and do not correspond to the anomalies observed in the
Upper Paddock to express variations between different saturation phases. Thus, the analysis of pore geometry impact on the results given by Kuster-Toksöz suggests that the physical modeling of carbonate rocks under the conditions imposed in this study resulted in an estimate of elastic modulus and density that corroborates the theoretical understanding of $V_{P}$ and $V_{S}$; and the inversion of elastic parameters, important to characterize heterogeneous reservoirs.

\section{ACKNOWLEDGMENTS}

Thanks are due to LENEP/UENF to the fundamental infrastructure support.

\section{REFERENCES}

ACUNA C. 2000. 4D multicomponent seismic characterization of Glorieta-Paddock carbonate reservoir at Vacuum field, New Mexico. Master of Science (Geophysics) thesis, Colorado School of Mines. 120 p.

ANSELMETTI FS \& EBERLI GP. 1999. The velocity deviation log: A tool to predict pore type and permeability trends in carbonate drill holes from sonic and porosity or density logs. AAPG Bulletin, 83: 450-466.

BATZLE M \& WANG Z. 1992. Seismic properties of pore fluids. Geophysics, 57: 1396-1408.

BERRYMAN JG. 1995. Mixture theories for rock properties. In Rock Physics and Phase Relations: a Handbook of Physical Constants, ed. T.J. Ahrens. Washington, DC: American Geophysical Union, 205-228.

BIOT MA. 1956. Theory of propagation of elastic waves in a fluid saturated porous solid: I. low frequency range. J. Acoustic Soc. Am., 28(2): 168-191.

CASTAGNA JP, BATZLE ML \& KAN TK. 1993. Rock physics - The link between rock properties and AVO response. In Offset-Dependent Reflectivity - Theory and Practice of AVO Analysis, ed. J.P. Castagna \& M. Backus. Investigations in Geophysics, 8, Society of Exploration Geophysicists, Tulsa, Oklahoma: 135-171.

ESCOBAR CHAPARRO CI. 2002. Caracterização das fácies calcárias da formação Cimarrona Campo Guanduas - VMM - Colômbia. Master Dissertation on Science in Civil Engineering: Universidade Federal do Rio de Janeiro. $120 \mathrm{p}$.

DUNHAM RJ. 1962. Classification of carbonate rocks according to depositional texture. AAPG Memoir, 1: 108-121.

FOLK RL. 1959. Practical petrographic classification of limestones. AAPG Bulletin, 43: 1-38.

FOLK RL. 1968. Petrology of sedimentary rocks. Hemphill's Austin, $170 \mathrm{p}$.

GASSMANN F. 1951. Über die elastizitat poroser medien: Verteljahrsschrist der Naturforschenden Gesellschaft in Zurich, 96: 1-23. 
GRAMMER GM, HARRIS PM \& EBERLI GP. 2004. Integration of Outcrop and Modern Analogs in Reservoir Modeling. AAPG Memoir, 80: 191214.

JACK I. 1997. Time-lapse Seismic in Reservoir Management: Distinguished Instructor Series. Society of Exploration Geophysicists, 1, Section 1.

KUMAR M \& HAN D. 2005. Pore shape effect on elastic properties of carbonate rocks. SEG Technical Program Expanded Abstracts, Society of Exploration Geophysicists, Houston Annual Meeting 2005: 1477-1481.

KUSTER GT \& TOKSÖZ MN. 1974. Velocity and attenuation of seismic waves in two-phase media, part I - theorical formulations. Geophysics, 39: 587-606.

MAVKO G, MUKERJI T \& DVORKIN J. 1998. The Rock Physics Handbook: Tools for Seismic Analysis in Porous Media. Cambridge University Press. $329 p$.

MOORE CH. 1989. Carbonate Diagenesis and Porosity. Developments in Sedimentology 46, Amsterdam, Elsevier Science Pub., 338 p.

NUR A, MAVKO G, DVORKIN J \& GALMUDI D. 1995. Critical porosity: The key to relating physical properties to porosity in rocks: $65^{\text {th }}$ Annual International Meeting, Society of Exploration Geophysicists, Expanded Abstracts: 878-881 pp.

PAYNE SS, WILD P \& LUBBE R. 2010. An integrated solution to rock physics modeling in fractured carbonate reservoirs. Society of Exploration Geophysicists, Technical Program Expanded Abstracts, Denver 2010 Annual Meeting: 358-362.
SPADINI AR \& MARÇAL RA. 2005. Porosidade em reservatórios carbonáticos: algumas considerações. Boletim de Geociências da Petrobras, Rio de Janeiro, 13(1): 129-138.

SUGUIO K. 1998. Dicionário de Geologia Sedimentar e Áreas Afins. Editora Bertrand Brasil: 620-623.

WALLS J \& DVORKIN J. 2005. Effects of pore fluid properties at high pressure and temperature on seismic response. Society of Exploration Geophysicists, Expanded Abstracts 24, Houston 2005 Annual Meeting: 1617-1621.

WANG HY, SUN SZ \& YANG HJ. 2009. Velocity prediction models evaluation and permeability prediction for fractured and caved carbonate reservoir: from theory to case study. $79^{\text {th }}$ Annual International Meeting, Society of Exploration Geophysicists, Expanded Abstracts: 2194-2198.

WANG HY \& SUN SZ. 2010. A full-frequency band Kuster-Toksöz model and its application in velocity dispersion analysis. Society of Exploration Geophysicists, Technical Program Expanded Abstracts, Denver 2010 Annual Meeting: 2522-2526.

WANG Z. 1997. Seismic Properties of Carbonate Rocks. In: PALAZ I \& MARFURT KJ (1997). Carbonate Seismology, Geophysical Developments, Society of Exploration Geophysicists, 6: 29-52.

XU S \& PAYNE MA. 2009. Modeling elastic properties in carbonate rocks. Special section: Rock Physics. The Leading Edge, 28(1): 66-74.

\section{NOTES ABOUT THE AUTHORS}

Irineu de A. Lima Neto holds a BS in Computer Science from the Universidade Cândido Mendes, Campos-RJ, Brazil, 2005. M.Sc. in Reservoir Engineering and Exploration applied Geophysics area, from LENEP/UENF; in 2008; where he is currently a Ph.D. student since 2011. Areas of interest are: seismic data processing, characterization of physical and mechanical properties of rocks and computer sciences applied to geophysics.

Roseane M. Misságia is a civil engineer from the Universidade Católica de Minas Gerais, PUC, Belo Horizonte, Brazil, in 1985. M.Sc. and Ph.D. in Reservoir Engineering and Exploration applied Geophysics area, from LENEP/UENF in 1988 and 2003. Currently, works as Associate Professor in the Geophysics department at LENEP/UENF. Areas on interest are: seismic data processing and characterization of physical and mechanical properties of rocks. 